\title{
Studi Kelayakan Investasi Perumahan Menggunakan Metode Benefit Cost Ratio
}

\author{
${ }^{1}$ Imam Sururi, ${ }^{2}$ Hammam Rofiqi Agustapraja \\ 1,2 Program Studi Teknik Sipil, Fakultas Teknik, Universitas Islam Lamongan \\ e-mail: ${ }^{1}$ sururii59@gmail.com, ${ }^{2}$ hammamrofiqi@unisla.ac.id
}

\begin{abstract}
Abstrak
Investasi merupakan pengaitan sebuah sumber keuangan dalam jangka waktu yang panjang untuk menghasilkan laba di masa depan/ masa yang akan datang. Perumahan merupakan sebuah kelompok rumah yang baik itu sempit ataupun luas yang berfungsi sebagai lingkungan tempat tinggal atau hunian bagi manusia yang menempatinya. Adapun rumusan masalah adalah untuk untuk mencari tau apakah rumah tipe 30/60 pada perumahan Insani Regency Lamongan ini layak untuk diinvestasikan bila ditinjau dari segi finansial. Tujuan dari penelitian ini adalah untuk mengetahui kelayakan investasi perumahan Insani Regency Lamongan. Metode yang digunakan untuk menganalisis Kelayakan investasi adalah Benefit Cost Ratio. Berdasarkan hasil dari penelitian Perumahan Insani Regency Lamongan ini menunjukkan layak karena menghasilkan nilai Benefot Cost Ratio sebesar 1,307.
\end{abstract}

Kata kunci: Investasi, Perumahan, Benefit Cost Ratio

\begin{abstract}
Investment is the association of a financial source in a long period to generate profits in the future/future. Housing is a group of houses that are either narrow or broad that functions as a residential or residential environment for the people who occupy it. The problem statement is to find out whether the house type 30/60 in the Lamongan Regency Insani housing is worth investing in when viewed from a financial perspective. The purpose of this study was to determine the feasibility of Insani Regency Lamongan housing investment. The method used to analyze the investment feasibility is the Benefit-Cost Ratio. Based on the results of this research, the Lamongan Regency Insani Housing showed that it was feasible because it produced a Benefit-Cost Ratio of 1,307.
\end{abstract}

Keywords: Investment, Housing, Benefit-Cost Ratio.

\section{Pendahuluan}

Sebuah bisnis properti ialah usaha untuk menanamkan modal dalam bentuk tanah atau bisa juga dalam bentuk bangunan, dan keuntungannya berupa perlindungan daya beli pada proses meningkatnya harga-harga perumahan secara terus menerus dan akan memperoleh nilai tambah dari pengembangannya (seperti dijadikan bangunan perumahan atau bangunan lainnya). Investasi adalah setiap pengeluaran modal atau dana baik itu diwujudkan berupa tanah atau bangunan yang ditanamkan dengan harapan dana atau modal tersebut akan diterima kembali baik dalam jangka pendek maupun dalam jangka panjang (Nino, dalam Manullang dkk, 2019). 
Apakah rumah tipe 30/60 pada perumahan Insani Regency Lamongan ini layak untuk diinvestasikan bila ditinjau dari segi finansial. Guna mengetahui rumah tipe 30/60 pada perumahan Insani Regency Lamongan layak untuk diinvestasi bila ditinjau dari segi finansial.

Besarnya dana yang diperlukan dalam investasi meliputi harga beli dan biaya yang harus dikeluarkan sampai aktiva tersebut siap pakai. Menurut (Husnan, dalam Manullang dkk, 2019), adapun sumber dana investasi yang utama, yaitu:

a. Modal sendiri diperoleh dari pemilik perusahaan. Dengan modal tersebutmaka perusahaan tidak mengeluarkan biaya lagi untuk pembayaran bunga.

b. Saham dapat berupa saham biasa atau saham preferen yang diperoleh dari emisi (penerbitan) saham dipasar modal. Perusahaan menghimpun dana masyarakat dengan jalan menerbitkan saham yang diperjualbelikan di bursa agar menghasilkan keuntungan.

c. Obligasi diterbitkan oleh perusahaan dan dijual di pasar modal.

d. Kredit Bank dapat berupa kredit investasi maupun non investasi. Bentuknya dapat berupa kredit jangka panjang, menengah, maupun pendek.

e. Sewa Guna Usaha (leasing) merupakan kegiatan pembiayaan perusahaan dalam bentuk penyediaan Adapun rumusan barang modal untuk digunakan suatu perusahaan (lessee) dalam jangka waktu tertentu berdasarkan pembayaran secara berkala disertai hak pilih bagi lessee untuk membeli terdapat didalam perumahan tersebut, yaitu luas tanah dan bangunan perumahan. barang modal tersebut atau memperpanjang jangka waktu leasing berdasarkan nilai sisa yang telah disepakati bersama. Leasing termasuk sumber dana yang berasal dari lembaga keuangan non-bank.

f. Project Finance merupakan bentuk kredit yang pembayarannya didasarkan atas kemampuan proyek tersebut melunasi kewajiban finansialnya.

Tanpa melakukan perbedaan terhadap investor institusional, yang terdiri dari lembaga-lembaga keuangan di luar perusahaan seperti perusahaan investasi, bank maupun pasar modal maka dalam suatu proses pengambilan keputusan investasi, sebagaimana dikatakan (Mulyadi dalam Santi, 2013) dilakukan melalui langkah- langkah sebagai berikut

1. Menetapkan Sasaran Investasi

2. Penentuan Kebijakan Investasi

3. Pemilihan Strategi Portofolio

4. Pemilihan Aset 
Investor harus memperhatikan faktor risiko (risk) dalam menentukan tingkat pengembalian (return). Definisi risiko menurut beberapa ahli adalah sebagai berikut. Menurut Fahmi (dalam Putra, 2013) secara umum risiko dapat ditangkap sebagai bentuk kejadian ketidakpastian tentang suatu kejadian yang akan terjadi nantinya dengan keputusan yang diambil berdasarkan suatu pertimbangan. Menurut Ahmad (dalam Putra, 2013) dalam pengertian investasi, risiko selalu dikaitkan dengan variabilitas return yang diperoleh dari surat berharga.

Perumahan adalah sebuah kelompok rumah yang berfungsi sebagai lingkungan tempat tinggal atau hunian manusia yang dilengkapi dengan prasarana lingkungan yaitu kelengkapan dasar fisik lingkungan, misalnya penyediaan air minum, pembuangan sampah, tersedianya listrik, telepon, jalan, yang memungkinkan lingkungan pemukiman berfungsi sebagaimana mestinya (Mukono dalam Xisuca, 2010).

Penelitian ini dilakukan pada proyek pembangunan Perumahan Insani Regency Lamongan yang terletak diJalan Dusun Koatan. Penelitian ini dilakukan selama 10 hari pada jam kerja (pukul 09.00-12.00 WIB) dengan adanya pengamatan pada ruang lingkup perumahan Insani Regency Lamongan.

\section{Metode}

Metode yang digunakan dalam penelitian ini yaitu Benefit Cost Ratio. Metode Benefit Cost Ratio adalah sebuah metode yang di gunakan untuk mengevaluasi pada proyek dengan membandingkan nilai sekarang (Present Value) dari seluruh manfaat / pendapatan yang biasa diperoleh oleh proyek tersebut dengan nilai sekarang dari seluruh biaya / pengeluaran proyek tersebut (Peni. R Pramono dalam Abadi, 2012). Rumus yang digunakan untuk menghitung nilai BCR menggunakan persamaan :

$$
\begin{aligned}
& \mathrm{B}=\mathrm{B} 0+\frac{\mathrm{B} 1}{(1+\mathrm{i})}+\underline{\mathrm{B} 2}+\ldots \ldots+\underline{\mathrm{Bn}} \\
& \mathrm{C}=\mathrm{C} 0+\frac{\mathrm{C} 1}{(1+\mathrm{i})}+\underline{\mathrm{C} 2}+\ldots \ldots \ldots+\underline{\mathrm{Cn}} \\
& \mathrm{BCR}=\frac{\mathrm{B}}{\mathrm{C}}
\end{aligned}
$$

Dimana :

$$
\begin{aligned}
& \mathrm{i}=\text { angka rate } \\
& \mathrm{n}=\text { umur proyek } \\
& \mathrm{B}=\text { benefit }
\end{aligned}
$$


$\mathrm{C}=$ cost

Apabila :

BCR $>1$ = investasi layak untuk dilakukan.

BCR $<1$ = investasi tidak layak untuk dilakukan.

\section{Hasil dan Pembahasan}

Hasil

Harga jual perumahan dapat dihitung dari sebuah besar biaya modal yang diperlukankan untuk membangun beberapa rumah itu kemudian ditambahkan dengan keuntungan yang ingin didapatkan oleh sebuah perusahaan. Harga pokok penjualan rumah adalah beban yang harus dapat ditutupi oleh harga jual perumahan. Perhitungan harga pokok penjualan perumahan harus mempertimbangkan komposisi unsur-unsur yang nilai bunga pada perhitungan harga jual ini didasarkan pada Bank BTN yaitu sebesar $5 \%$ flat/tahun.

Tabel 1 menggambarkan uraian tentang biaya yang dibutuhkan dalam membangun perumahan.

Tabel 1 Biaya Total Pembangunan Perumahan Insani Regency Lamongan

\begin{tabular}{|c|c|c|c|}
\hline No. & Uraian & & Jumlah \\
\hline 1. & Biaya Pembangunan Perumahan & & 1.403 .116 .400 \\
\hline 2. & Biaya Pembelian Tanah & Biaya Total & $\begin{array}{r}200.178 .000 \\
1.603 .294 .400\end{array}$ \\
\hline
\end{tabular}

Sebelum menentukan harga jual perumahan ada beberapa hal yang harus diketahui yaitu biaya untuk pembangunan perumahan Rp 1.403.116.400,00. Dan biaya pembelian tanah perumahan sebesar Rp 200.178.000,00 maka beban/biaya yang harus ditutupi oleh harga jual rumah adalah $\mathrm{Rp}$ 1.603.294.400,00.

Tabel 2 menggambarkan luas tanah dan bangunan rumah tipe 30/60 pada perumahan Insani Regency Lamongan.

Tabel 2 Luas Tanah dan Bangunan Rumah

\begin{tabular}{llccc}
\hline No. & Uraian & Luas (m2) & Jumlah & Ukuran \\
\hline 1. & Luas tanah Rumah T 30/60 & 900 & 15 & 60 \\
2. & Luas bangunan Rumah T & 450 & 15 & 30 \\
\hline
\end{tabular}

Luas bangunan rumah dan tanah, luas bangunan rumah tipe 30/60 jumlahnya ada 15 unit dengan ukuran 30/m2 total luas bangunan rumah adalah 450m2. Dan luas tanah pembangunan rumah tipe 30/60 ada 15 unit dengan ukuran 60/m2 untuk luas 1 unitnya, jadi luas total tanah untuk perumahan adalah 900m2. Tabel menggambarkan uraian tentang HPP. 
Tabel 3 Harga Pokok Penjualan Unit Rumah

\begin{tabular}{ccc}
\hline No. & Uraian & Biaya Total \\
\hline 1. & Pembangunan Rumah Tipe 30/60 & 1.603 .294 .400 \\
No. & Uraian & Biaya/Unit \\
1. & Harga Pokok Penjualan Unit Rumah & 106.886 .293 \\
\hline
\end{tabular}

Harga pokok penjualan unit rumah adalah Rp 106.886.293,00 nilai tersebut didapatkan dari jumlah total biaya pembangunan rumah tipe 30/60 sebesar $\mathrm{Rp}$ 1.603.294.400,00 di bagi banyaknya unit rumah yaitu 15 unit.

Pada tabel 4 ditunjukkan asumsi dasar pehitungan harga jual perumahan Insani Regency Lamongan :

Tabel 4 Asumsi dasar perhitungan harga jual perumahan

\begin{tabular}{llll}
\hline No & Harga penjualan unit rumah & Jumlah $(\mathrm{U})$ & \multicolumn{1}{c}{ Harga pokok } \\
\hline 1 & Rumah T. 30/60 & 15 & 106.886 .293 \\
& Harga/unit & U.muka (\%) & Uang muka \\
& 150.000 .000 & $30 \%$ & 45.000 .000 \\
& Jumlah Kredit & Angsuran & Perbulan \\
& 105.000 .000 & 1.600 .000 & 24.000 .000 \\
\hline
\end{tabular}

Harga jual rumah tipe 30/60 ialah sebesar Rp 150.000.000, dengan asumsi uang muka sebesar 30\% jika dirupiah adalah sebesar Rp 45.000.000. Jumlah beban kredit rumah sebesar Rp 105.000.000, dapat diangsur setiap bulannya sebesar $\mathrm{Rp} 1.600 .000$ total uang yang diterima perusahaan setiap tahunnya angsuran perbulan dikalikan total jumlah rumah yang terjual.

Tabel 5 merupakan perhitungan pendapatan penjualan perumahan Insani Regency Lamongan.

Tabel 5 Perhitungan Pendapatan Penjualan Perumahan

\begin{tabular}{ccccc}
\hline No & Pendapatan Penjualan & Jumlah & Harga/unit & Total \\
\hline 1. & Rumah T. 30/60 & 15 & 150.000 .000 & 2.250 .000 .000
\end{tabular}

Perumahan Insani mematok harga jual perumahan sebesar Rp 150.000.000 dan total pembangunan perumahan mencapai 15 unit rumah di kalikan harga jual rumah, jadi perumahan Insani mendapatkan dana penjualan rumah sebesar $R p$ 2.250.000.000. Tabel 6 merupakan penerimaan uang kas dari hasil penjualan perumahan. 
Tabel 6 Penerimaan Uang Kas

\begin{tabular}{cccccc}
\hline No & $\begin{array}{c}\text { Penerimaan Uang } \\
\text { muka pembelian }\end{array}$ & $30 \%$ & 2019 & 2020 & 2021 \\
\hline 1. & $\begin{array}{c}\text { Rumah T. 30 } \\
\text { Pendapatan }\end{array}$ & Unit & $\begin{array}{c}12 \\
540.000 .000\end{array}$ & $\begin{array}{c}3 \\
135.000 .000\end{array}$ & 0 \\
\hline No & Pend. Dari bank & $70 \%$ & 2019 & 2020 & 2021 \\
\hline 1. & Rumah T. 30 & Unit & 7 & 8 & 0 \\
& Pendapatan & & 735.000 .000 & 840.000 .000 & 0 \\
2. & Penerimaan kas total & & 1.275 .000 .000 & 975.000 .000 & 0 \\
\hline
\end{tabular}

Pada tahun 2019 perusahaan mendapatkan uang muka pembelian perumahan sebesar $\mathrm{Rp} 540.000 .000,00$ nilai tersebut didapatkan dari Rp 45.000.000,00 dikalikan 12 unit rumah yang terjual dalam satu tahun. Sedangkan pada tahun 2020 peruahaan kembali mendapatkan uang dari hasil penjualan perumahan sebesar Rp 135.000.000,00 dari penjualan 3 unit rumah dikalikan Rp 45.000.000,00. Dan pada tahun 2021 perusahan tidak mendapatkan apa-apa karena perumahan sudah habis terjual.

Penerimaan uang dari bank diproyeksikan akan cair 7 unit dikalikan $\mathrm{Rp}$ 105.000.000,00. Maka perusahaan mendapatkan uang dari bank sebesar Rp 735.000.000,00. Sedang pada tahun 2020 perusahan kembali mendapatkan dana dari bank sebesar Rp 840.000.000,00 nilai tesebut didapatkan dari hasil pencairan dana kredit dari bank sebanyak 8 unit dikalikan Rp 105.000.000,00. Dan pada tahun 2021 perusahan tidak mendapatkan apa-apa karena dana yang cair dari bank telah selesai pada tahun 2020 .

Jadi penerimaan kas total pembangunan perumahan Insani yaitu sebesar Rp 2.250.000.000,00. Nilai tersebut didapatkan dari penerimaan uang kas pembelian perumahan dan penerimaan uang dari bank selama 2 tahun. Tabel 7 merupakan perhitungan Pendapatan tunai dan pengeluaran tunai perumahan Insani Regency Lamongan.

Tabel 7 Pendapatan tunai

\begin{tabular}{clrcc}
\hline No & \multicolumn{1}{c}{ Uraian } & 2019 & 2020 & 2021 \\
\hline A. & Pendapatan Tunai & & & \\
1. & $\begin{array}{l}\text { U. Muka Pembelian } \\
\text { Rumah T.30 }\end{array}$ & 540.000 .000 & 135.000 .000 & 0 \\
\hline 2. & $\begin{array}{l}\text { Pembayaran Dari Bank } \\
\text { Rmh T.30 }\end{array}$ & 735.000 .000 & 840.000 .000 & 0 \\
& Total Pendapatan Tunai & 1.275 .000 .000 & 975.000 .000 & 0 \\
\hline
\end{tabular}


Pada tahun 2019 perusahaan menerima uang muka pembelian rumah tipe 30/60 sebesar Rp 540.000.000,00. Jumlah tersebut adalah hasil dari penerimaan uang muka pembelian rumah sebesar Rp 45.000.000,00 dikalikan 12 unit rumah. Sama halnya dengan tahun 2019, sedangkan pada tahun 2020 perusahaan kembali mendapatkan uang muka hasil pembelian rumah sebesar $\mathrm{Rp}$ 135.000.000,00. Itu merupakan hasil dari Rp 45.000.000,00 dikalikan 3 unit rumah yang terjual. Sedangkan pada tahun 2021 perusahaan tidak menerima apa-apa karena semua dana sudah clear tahun 2020.

Pembayaran dari bank untuk rumah tipe 30/60 pada tahun 2019 cair sebesar Rp 735.000.000,00. Nilai nominal uang tersebut berasal dari jumlah kredit harga rumah sebesar $\mathrm{Rp}$ 105.000.000,00 dikalikan 7 unit. Tahun 2020 perusahaan kembali menerima uang dari bank sebesar Rp 840.000.000,00. Jumlah tersebut adalah hasil dari besar uang kredit rumah dari bank yaitu Rp 105.000.000,00 dikalikan jumlah 8 unit rumah yang cair dari bank. Sedangkan pada tahun 2021 perusahaan tidak menerima apa-apa karena semua dana sudah clear tahun 2020. Jadi total pendapatan Jadi total pendapatan tunai pada tahun 2019 adalah Rp 1.275.000.000,00 dan total pendapatan pada tahun 2020 adalah $\mathrm{Rp}$ $975.000 .000,00$.

Tabel 8 Pengeluaran Tunai

\begin{tabular}{clccc}
\hline No. & Pengeluaran Tunai & 2019 & 2020 & 2021 \\
\hline 1. & Biaya Pembangunan & 855.090 .344 & 748.204 .051 & 0 \\
& Total pengeluaran Tunai & 855.090 .344 & 748.204 .051 & 0 \\
& Net Cash Inflow & 419.909 .656 & 226.795 .949 & 0 \\
\hline
\end{tabular}

Berdasarkan tabel 8, pengeluaran biaya untuk pembangunan rumah pada tahun 2019 adalah Rp 106.886.293,00 dikalikan 8 unit rumah yang dibangun, jadi total biaya yang dibutuhkan untuk membangun rumah pada tahun 2019 yaitu $\mathrm{Rp}$ 855.090.344,00. Sedangkan pada tahun 2020 perusahaan kembali mengeluarkan uang untuk 748.204.051,00. Nilai tersebut didapatkan dari Rp 106.886.293 dikalikan 7 unit rumah.

Pengeluaran biaya untuk Jadi total dari Net Cash Inflow pada tahun 2019 adalah Rp 419.909.656,00 merupakan hasil dari penerima uang muka pembelian rumah tipe 30/60 tahun 2019 dikurangi dengan pengeluaran biaya untuk pembangunan rumah tahun 2019. Dan total Net Cash Inflow pada tahun 2020 adalah 226.795.949,00. Merupakan hasil dari penerima uang muka pembelian rumah tipe 30/60 tahun 2020 dikurangi dengan pengeluaran biaya untuk 
pembangunan rumah pada tahun 2020.

Proyeksi Benefit Cost Ratio

Benefit Cost Ratio merupakan perbandingan nilai keuntungan yang didapatkan oleh perusahaan dengan nilai sekarang dari seluruh biaya proyek. Bunga yang digunakan untuk perhitungan nilai BCR ialah sebesar $10 \%$, diasumsikan dari presentase besar biaya modal. Biaya modal ialah imbalan yang diharapkan oleh seorang investor atas penanaman modal yang dilakukannya. Penjualan Perumahan ini menggunakan system pesan langsung dibangun, sehingga proses pengeluaran biaya yang dipakai untuk membangun perumahan mengikuti proyeksi penjualan unit rumah.

Diketahui :

Investasi $(\mathrm{I})=\mathrm{Rp}$ 1.603.294.400

Annual Benefit (Ab) tahun $1=$ Rp 1.275.000.000

Annual Benefit $(\mathrm{Ab})$ tahun $2=\mathrm{Rp} 975.000 .000$

Annual Cost (Ac) tahun $1=\mathrm{Rp}$ 855.090.344

Annual Cost $(\mathrm{Ac})$ tahun $2=\mathrm{Rp} 748.204 .051$

Umur Investasi $(n)=2$ tahun

Suku bunga $(i)=10 \%$

Net cash Inflow pada tahun 2019 Rp 419.909.656

Net cash Inflow pada tahun 2020 Rp 226.795.949

Dimana :

$$
\begin{aligned}
& \mathrm{i}=\text { angka rate } \quad \mathrm{C}=\text { cost } \\
& \mathrm{n}=\text { umur proyek } \\
& \mathrm{B}=\text { benefit }
\end{aligned}
$$

Dibawah ini adalah perhitungan dari Benefit Cost Ratio :

$$
\begin{aligned}
& \mathrm{B}=\mathrm{B} 0+\frac{\mathrm{B} 1}{(1+\mathrm{i})}+\frac{\mathrm{B} 2}{(1+\mathrm{i}) 2}+\ldots \ldots+\frac{\mathrm{Bn}}{(1+\mathrm{i}) \mathrm{n}} \\
& \mathrm{C}=\mathrm{C} 0+\frac{\mathrm{C} 1}{(1+\mathrm{i})}+\frac{\mathrm{C} 2}{(1+\mathrm{i}) 2}+\ldots \ldots+\frac{\mathrm{Cn}}{(1+\mathrm{i}) \mathrm{n}}
\end{aligned}
$$

$$
\begin{aligned}
\mathrm{BCR} & =\frac{\mathrm{B}}{\mathrm{C}} \\
\mathrm{B}=\mathrm{B} 0 & +\frac{1.125 .000 .000}{(1+2,5937)}+\frac{975.000 .000}{(1+0,3855) 2} \\
& =\frac{1.125 .000 .000}{3,5937}+\frac{975.000 .000}{1,91961025} \\
& =313.047 .834+507.915 .605
\end{aligned}
$$




$$
\begin{aligned}
& =820.963 .439 \\
C=C 0 & +\frac{855.090 .344}{(1+2,5937)}+\frac{748.204 .051}{(1+0,3855) 2} \\
& =\frac{855.090 .344}{3,5937}+\frac{748.204 .051}{1,91961025} \\
& =237.941 .493+389.768 .730 \\
& =627.710 .223 \\
B C R & =\frac{820.963 .439}{627.710 .223} \\
& =1,307
\end{aligned}
$$

Apabila :

BCR $>1$ = investasi layak untuk dilakukan.

$\mathrm{BCR}<1$ = investasi tidak layak untuk dilakukan.

Setelah dilakukan tahap analisa data diatas nilai benefit sebesar Rp1.125.000.000 di tambahkan dengan Benefit kedua sebesar Rp975.000.000 sebesar kemudian di bagi angka rate masing-masing. Dan menghitung nilai cost pertama sebesar Rp855.090.344 ditambahkan dengan nilai cost kedua sebesar Rp748.204.051 lalu dibagi angkat rate yang ada di bawahnya, kemudian nilai benefit total sebesar Rp820.963.439 di bagi cost total sebesar Rp627.710.223 jadi hasilnya adalah 1,307 > 1, maka investasi tersebut layak untuk dijalankan.

\section{Pembahasan}

Berdasarkan hasil dari penelitian yang dilakukan Pada PT. Cipta Griya Insani lebih tepatnya pada perumahan Insani Regency Lamongan. Diketahui biaya awal Investasi pembangunan rumah sebesar Rp 1.603.294.400, disamping itu untuk mengoperasikan pembangunan perumahan tersebut dibutuhkan biaya operasional tahun pertama sebesar $\mathrm{Rp}$ 855.090.344 dan tahun kedua adalah $\mathrm{Rp} R p$ 748.204.051. Selanjutnya dari hasil penjualan perumahan akan ada pemasukkan tahun pertama sebesar $\mathrm{Rp}$ 1.275.000.000 dan tahun kedua mendapatkan pemasukkan sebesar Rp 975.000.000. Serta umur investasi adalah 2 tahun, perhitungan benefit tahun satu ditambahkan dengan benefit tahun kedua kemudian di bagi dengan angka rate masing yang telah terhitung pada hasil penelitian di atas, kemudian menghitung nilai cost tahun pertama ditambahkan dengan nilai cost tahun kedua lau dibagi dengan angka rate masing-masing tahun seperti yang 
ada diHasil Penelitian di atas. Kemudian nilai benefit yang telah di hitung dibagi dengan nilai cost, hasilnya adalah 820.963.439 dibagi dengan 627.710.223 nilai yang didapatkan dari perhitungan tersebut yaitu 1,307.

\section{Kesimpulan}

Berdasarkan Hasil Penelitian yang dilakukan Pada PT. Griya Cipta Insani selaku pengembang perumahan Insani Regency Lamongan, investasi yang dilakukan oleh PT Griya Cipta Insani ini layak untuk dilakukan karena nilai Benefit Cost Ratio bernilai $1,307>1$.

\section{Daftar Pustaka}

Abadi, A. N. (2012). Studi kelayakan investasi properti proyek pembangunan perumahan citra alam mandiri Sukoharjo, Kota Surakarta.

Manullang, D. W., Karamoy, H., \& Pontoh, W. (2019). Analisis Kelayakan Investasi Aktiva Tetap (Studi Kasus Pada Cincau Jo, Blencho Dan Brownice Unit Kreativitas Mahasiswa Universitas Sam Ratulangi). Jurnal EMBA: Jurnal Riset Ekonomi, Manajemen, Bisnis dan Akuntansi, 7(2). Kota Manado

Xisuca, (2010). Definisi Perumahan dan Rumah. Dikutip dari http://xisuca.blogspot.com/2010/06/definisi-perumahan-dan-rumah.html

Putra, R. (2013). Analisis Pemilihan Investasi Saham dengan menggunakan Metode CAPM dan RVAR Sebagai Penentu Pengambilan Keputusan Investasi Saham (Studi pada Perusahaan-Perusahaan yang Listing pada Indeks LQ45 di Burs (Doctoral dissertation, Universitas Brawijaya).

Santi, G. (2013). Sistem Informasi Akuntansi Manajemen Dalam Pengambilan Keputusan Investasi Pada PT. Bank Sulut Cabang Marina Plaza. Jurnal EMBA: Jurnal Riset Ekonomi, Manajemen, Bisnis dan Akuntansi, 1(3). 